III. THE CARBON CYCLE 
[RADIOCARBON, VOL 28, No. 2A, 1986, P 309-327]

\title{
CARBON CYCLE: 1985 \\ GLACIAL TO INTERGLACIAL CHANGES IN THE OPERATION OF THE GLOBAL CARBON CYCLE
}

\author{
WALLACE S BROECKER \\ Lamont-Doherty Geological Observatory, Palisades, New York 10964 \\ and \\ TSUNG-HUNG PENG \\ Oak Ridge National Laboratory, Oak Ridge, Tennessee 37830
}

\begin{abstract}
The hottest topic for those interested in the earth's carbon cycles is the change in atmospheric $\mathrm{CO}_{2}$ content between glacial and interglacial time. What caused it? What is its role in glacial cycles? We evaluate here the hypotheses that have been put forward to explain the $\mathrm{CO}_{2}$ change with evidence from deep sea sediments. We conclude that all the hypotheses have serious drawbacks and that much effort will have to be expended in gathering more data from ice cores and ocean sediments before we will be pointed toward the correct scenario. Also, thoughtful modeling aimed at depicting the ties between $\mathrm{pCO}_{2}, \mathrm{O}_{2},{ }^{13} \mathrm{C} /{ }^{12} \mathrm{C},{ }^{14} \mathrm{C} /{ }^{12} \mathrm{C}$, and nutrient constituents in the sea for various modes of circulation will have to be done before the evidence from ocean cores can be properly interpreted.
\end{abstract}

\section{INTRODUCTION}

Nearly a decade has passed since Shackleton (1977) demonstrated that the ${ }^{13} \mathrm{C} /{ }^{12} \mathrm{C}$ ratio in the carbon dissolved in the deep ocean was lower during glacial than interglacial times. As ca $85 \%$ of the carbon in the oceanatmosphere-biosphere pool resides in the deep ocean, its ${ }^{13} \mathrm{C} /{ }^{12} \mathrm{C}$ change likely typifies that for the entire pool. Shackleton's explanation for this difference was that the forest-soil carbon reservoir was smaller during glacial than during interglacial time. For the same reason that growth and retreat of ice caps (deficient in ${ }^{18} \mathrm{O}$ ) causes the oxygen isotopic composition of ocean water to change, growth and retreat of forest-soil organics (deficient in ${ }^{13} \mathrm{C}$ ) causes the carbon isotopic composition of ocean carbon to change. This finding suggests less biosphere and hence higher atmospheric $\mathrm{CO}_{2}$ content during glacial time.

Two groups then reported measurements of the $\mathrm{CO}_{2}$ content of gasses trapped in polar ice of glacial age (Delmas, Ascencio \& Legrand, 1980; Berner, Oeschger \& Stauffer, 1980). Contrary to the implications of Shackleton's ${ }^{13} \mathrm{C}$ results, both groups concluded that the $\mathrm{CO}_{2}$ content of the glacial atmosphere was substantially lower than today.

A hypothesis that allowed these seemingly conflicting results to be reconciled was later published (Broecker, 1981). The idea was that the ${ }^{13} \mathrm{C}$ / ${ }^{12} \mathrm{C}$ change for ocean carbon was caused mainly by the storage of organic compounds in shelf sediments deposited during the marine transgression that accompanied deglaciation. If the $\mathrm{P}$ (and $\mathrm{N}$ ) to $\mathrm{C}$ ratio in this organic debris was similar to that for average marine plankton and if the loss to the sediments of organic carbon was compensated by excess accumulation of $\mathrm{CaCo}_{3}$ on the sea floor, then the glacial to Holocene $\mathrm{CO}_{2}$ change would be of the sense observed in ice cores. This hypothesis predicted that the difference between the $\delta^{13} \mathrm{C}$ value for planktonic forams living in warm surface waters and benthic forams should have been larger during glacial time than 
during the Holocene. Broecker $\left(1982 \mathrm{a}\right.$, b) pointed to ${ }^{13} \mathrm{C} /{ }^{12} \mathrm{C}$ data from planktonic and benthic foraminifera in support of this prediction.

While attractive, the shelf hypothesis has several drawbacks. The ocean sediment ${ }^{13} \mathrm{C} /{ }^{12} \mathrm{C}$ record points to a smaller $\mathrm{CO}_{2}$ change than is observed in ice cores. The required amount of sediment deposition on the shelves pushes the upper limit of credibility. Shackleton's forest-soil contribution to the deep ocean ${ }^{13} \mathrm{C} /{ }^{12} \mathrm{C}$ ratio change has to be reduced to the lower limit of credibility. Further, as the time constant for $\mathrm{CaCO}_{3}$ compensation is several thousand years, a substantial delay between the ice volume and $\mathrm{CO}_{2}$ change would be expected. No indication of such a delay is seen in the available ice core data. The hypothesis demands that the $\mathrm{O}_{2}$ content of glacial deep ocean water was much lower than today's. Unfortunately, our ability to reconstruct paleo- $\mathrm{O}_{2}$ changes for the deep sea is not good. However, had the deep sea been very low in $\mathrm{O}_{2}$ content during glacial time, higher organic carbon contents would be expected in glacial than in interglacial sediment. As evidence for such changes is seen in sediments from only very limited parts of the sea floor, a glacial deep ocean with very low oxygen content seems unlikely.

In the last five years, an abundance of new data bearing on this problem has been produced and much thought has been given to hypotheses that might explain these data (much of this evidence is discussed in Sundquist \& Broecker, 1985). Unfortunately, no broadly acceptable hypothesis has yet been found. Our purpose here is to provide a status report as of December 1985.

\section{VALIDITY OF THE ATMOSPHERIC $\mathrm{CO}_{2}$ RECORD}

One easy way out of the dilemma would be to challenge the validity of the ice-core-based glacial to interglacial atmospheric $\mathrm{CO}_{2}$ change. But the work of the last five years strengthens rather than undermines the original claims. The ca $200 \times 10^{-6}$ atm $\mathrm{CO}_{2}$ partial pressure for the glacial atmosphere has now been documented by measurements on five ice cores (Camp Century, Neftel et al, 1982; Dye 3, Stauffer et al, 1984; Byrd, Neftel et al, 1982; Dome C, Delmas, Ascencio \& Legrand, 1980; Vostok, D Raynaud, pers commun). Because these cores come from sites of large range in accumulation rate $(3 \mathrm{~cm} / \mathrm{yr}$ to $30 \mathrm{~cm} / \mathrm{yr})$ and mean annual air temperature $\left(-22^{\circ} \mathrm{C}\right.$ to $\left.-50^{\circ} \mathrm{C}\right)$, and because the glacial sections in these cores range from acid (Dome C) to alkaline (Dye 3, Camp Century), the result is independent of obvious environmental parameters that might cause biases. Close agreement has also been obtained on the $\mathrm{CO}_{2}$ content of air trapped in ice covering the period $\mathrm{AD} 1500$ to 1850 by the Bern and Grenoble labs (Barnola et al, 1983). While the absolute $\mathrm{CO}_{2}$ contents are still in question at the level of $\pm 10 \times 10^{-6} \mathrm{~atm}$, the glacial to interglacial difference of ca $75 \times 10^{-6} \mathrm{~atm}$ appears to be firm (glacial $\mathrm{pCO}_{2} \simeq 200 \times 10^{-6} \mathrm{~atm}$ and interglacial $\mathrm{pCO}_{2} \simeq 275 \times 10^{-6} \mathrm{~atm}$ ).

There is one seeming flaw in the ice-core record. Stauffer et al (1984) report rapid $\left(<200\right.$ years) $\mathrm{CO}_{2}$ changes with magnitudes of $\simeq 50 \times 10^{-6}$ atm associated with brief $\delta^{18} \mathrm{O}$ warm events in the Dye 3 Greenland record. The Bern group pointed at the possibility that these shifts might be artifacts, 
especially since the mean annual air temperature at Dye 3 is relatively high. The rapidity of these shifts poses a particularly difficult task for those developing hypotheses to explain $\mathrm{CO}_{2}$ changes. Despite a concerted effort by the Bern group, brief $\mathrm{CO}_{2}$ highs of comparable size have not yet been found in the Byrd Station Antarctica $\mathrm{CO}_{2}$ record (Neftel, Oeschger \& Stauffer, pers commun). Unlike ${ }^{18} \mathrm{O}$ or dust records which might show significant Antarctic to Greenland differences, the $\mathrm{CO}_{2}$ record must be global.

There are three possible explanations for this apparent flaw:

1) The Dye 3 site is at too low an elevation to be suitable for gas studies of warm events. The problem is that during Holocene time melting occurred during some summers. As shown by Stauffer et al (1985), when melt waters refreeze, ice has a $\mathrm{CO}_{2}$ content ca 20 times higher than originally. We could postulate that during the warm events partial melting yielded anomalously high $\mathrm{CO}_{2}$ contents. The problem with this explanation is that it requires that all the samples from the warm events studied by Stauffer et al (1984), have $6 \pm 2 \%$ melt ice. This uniformity is highly unlikely. Also, the Bern group has now found the same $\mathrm{CO}_{2}$ change for one of the warm events in the Camp Century core (Oeschger et al, pers commun). As the current mean annual temperature at the Camp Century site is $4^{\circ} \mathrm{C}$ colder than that for the Dye 3 site, the likelihood of summer melting is much reduced.

2) Some complicated tectonic phenomena caused the warm and cold ice to be shuffled like a deck of cards. There is no known physical mechanism to produce such a shuffling. Further, as warm elements do not show the full interglacial signature, these "cards" would have to have been produced when the climate was intermediate between that of full glacial and full interglacial. No obvious source for such ice exists in the record. Also, Dansgaard et al $(1982,1984)$ and Dansgaard (1985) show that the events in the Dye 3 core correlate well with those in the Camp Century core.

3) The time represented by a single warm event is so brief that in Antarctica where accumulation rates are very low they are short compared to the closure period for air inclusions in the ice. In the 1840-1910 meter interval of the Dye 3 core (Stauffer et al, 1984) there are 8 warm events. They comprise ca $1 / 3$ of the ice in this depth interval which has a duration of ca 18,000 years. Thus, if the duration of the event is in proportion to its thickness, then the average duration of the warm events is ca 750 years. However, the ${ }^{10}$ Be data on Dye 3 (Beer et al, 1984) suggest that the accumulation rate during the warm events was twice as great as during the cold events. If so, then the duration of the average warm event drops to 450 years. As the climatic changes associated with these events are not seen in the Antarctic record, their contribution to the record is probably in proportion to their duration. If so, in Antarctica they constitute $20 \%$ of the record. Were the warm events in Antarctica totally blurred by a long closure interval, then taking the cold interval $\mathrm{CO}_{2}$ content to be $200 \mathrm{ppm}$ and the warm interval $\mathrm{CO}_{2}$ content to be $250 \mathrm{ppm}$, the blurred reading would be $210 \mathrm{ppm}$. This difference is too small to be significant. According to the estimates of Schwander and Stauffer (1984), the current closure time at the Byrd site is 54 years. For the colder and lower accumulation conditions of 
the glacial it may have been as high as 150 years. Hence, this explanation appears to fall short. There is, however, another possible explanation for the absence of $\mathrm{CO}_{2}$ changes in the Antarctic record. The low dust content ice that characterizes the warm events is several times more viscous than the high dust content ice that characterizes the cold events (Gunderstrup \& Hansen, 1984; Dahl-Jensen, 1985). It is possible that this difference leads to a separation during flow of the warm event ice into boudins (as is the case for dolomite in deformed layered carbonate sediments). If so, the time represented by the warm events may be even smaller than 450 years.

The warm event problem remains unresolved. Resolution may have to await the drilling of a new Greenland ice core at the proposed high elevation Crete site.

A major deficiency in the $\mathrm{CO}_{2}$ record is the sparsity of data for the glacial to Holocene transition. As different hypotheses lead to different predicted shapes, lags, and durations for this transition, reliable documentation in cores from both Antarctica and Greenland is of utmost importance. The Dome $\mathrm{C}$ record shows a pair of sharp $\mathrm{CO}_{2}$ maxima during the transition, which Raynaud believes to be real. However, until they are documented in a second core, the oscillations are not likely to be given serious attention.

\section{TEMPERATURE EFFECT}

The most obvious means of reducing the atmosphere's $\mathrm{CO}_{2}$ concentration during glacial time is to cool the surface ocean. The atmosphere's $\mathrm{CO}_{2}$ content is reduced by ca $3 \%$ for each $1{ }^{\circ} \mathrm{C}$ the surface ocean is cooled. To increase the $\mathrm{CO}_{2}$ content from $200 \times 10^{-6}$ atm (the glacial value) to $275 \times$ $10^{-6} \mathrm{~atm}$ (the interglacial value) would require a $10^{\circ} \mathrm{C}$ warming.

Based on the faunal record in ocean sediments the CLIMAP group concluded that the average glacial to interglacial sea surface temperature warming was only $1.7^{\circ} \mathrm{C}$. Oxygen isotope evidence from planktonic and benthic forams places an upper limit of ca $2^{\circ} \mathrm{C}$ on this difference (see Broecker, in press, for summary). In the absence of any other change, a $1.7^{\circ} \mathrm{C}$ warming produces a $14 \times 10^{-6} \mathrm{~atm}$ increase in the atmospheric $\mathrm{CO}_{2}$ partial pressure.

\section{SALINITY EFFECT}

Because of the storage of water in continental ice caps, the sea must have been saltier during glacial time. Taking the volume of excess continental ice to be $55 \times 10^{6} \mathrm{~km}^{3}$ (equivalent to a $150 \mathrm{~m}$ lowering of sea level) the salinity of sea water was ca $4 \%$ higher during glacial time than it is now. This applies to the sea's alkalinity and the sea's $\Sigma \mathrm{CO}_{2}$ concentration, as well as to its $\mathrm{Na}^{+}, \mathrm{Cl}^{-}, \ldots$ concentrations. The salinity decrease at the close of glacial time would lower the $\mathrm{CO}_{2}$ of the atmosphere by ca $14 \times 10^{-6} \mathrm{~atm}$. This decrease approximately cancels the temperature-induced $\mathrm{CO}_{2}$ increase.

\section{ORGANIC MATTER INVENTORY EFFECT}

Shackleton (1977) indicates that paleogeographic reconstructions lead to lower living biomass inventories during the glacial period than during 
the Holocene. Lands that now support the temperate forests of the northern hemisphere were covered either by ice sheets or tundra. The tropics appear to have been drier, with expanded deserts, savannas, and reduced rain forests. While difficult to quantify, it is possible that the living biomass was reduced to half of today's quantity. This corresponds to the addition of $2.5 \times 10^{16}$ moles of $\mathrm{CO}_{2}$ to the ocean-atmosphere reservoir during glacial time. If not compensated for by excess $\mathrm{CaCO}_{3}$ deposition, this addition leads to an increase in atmospheric $\mathrm{CO}_{2}$ content of $25 \times 10^{-6} \mathrm{~atm}$. If compensated for by excess $\mathrm{CaCO}_{3}$ deposition, it would lead to a ca $4 \times 10^{-6} \mathrm{~atm}$ increase in $\mathrm{CO}_{2}$ pressure.

$\mathrm{CaCO}_{3}$ compensation in the ocean is part of its natural chemical control system (Broecker, 1971). In today's sea, $\mathrm{CaCO}_{3}$ is produced by marine organisms at a rate several times the supply rate of $\mathrm{CaCO}_{3}$ to the sea. Thus, for the loss of $\mathrm{CaCO}_{3}$ to sediments to match the supply from rivers, most of the $\mathrm{CaCO}_{3}$ formed must redissolve. The balance is maintained through changes in the $\mathrm{CO}_{3}{ }^{=}$content of the deep sea. Sudden removal of $\mathrm{CO}_{2}$ from the ocean-atmosphere reservoir to form plant matter raises the $\mathrm{CO}_{3}{ }^{=}$ion content of sea water. This in turn creates a mismatch between $\mathrm{CaCO}_{3}$ burial and $\mathrm{CaCO}_{3}$ supply. $\mathrm{CaCO}_{3}$ accumulates faster than it is supplied to the sea. This burial of excess $\mathrm{CaCO}_{3}$ in marine sediment draws down the $\mathrm{CO}_{3}{ }^{=}$concentration of sea water toward the value required for balance between $\mathrm{CaCO}_{3}$ loss and gain. In this way the ocean "compensates" for organic removal. As a consequence of this compensation process, the $\mathrm{CO}_{2}$ content of the atmosphere rises back toward its initial value.

If organic carbon is assumed to have a mean $\delta^{13} \mathrm{C}$ value of $-26 \%$, the $\delta^{13} \mathrm{C}$ calue for mean ocean-atmosphere carbon would have increased by $0.16 \%$ due to the early Holocene reforestation. Although still quite uncertain, based on ${ }^{13} \mathrm{C} /{ }^{12} \mathrm{C}$ ratio measurements on forams now available, the mean $\delta^{13} \mathrm{C}$ value for ocean-atmosphere carbon appears to have been ca $0.5 \%$ lower during glacial time than during the Holocene. If so, the difference between the observed $0.5 \%$ change and the forest-induced $0.16 \% 0$ change must be the result of increases during the early Holocene in the amount of carbon stored in soils and in marine sediments. Hence, a transfer of $7.5 \times 10^{16}$ moles of carbon from the ocean-atmosphere reservoir to organic reservoirs must be called upon to explain the glacial to Holocene ocean ${ }^{13} \mathrm{C} /{ }^{12} \mathrm{C}$ change. This would produce a $\mathrm{pCO}_{2}$ decrease of $75 \times 10^{-6}$ atm without $\mathrm{CaCO}_{3}$ compensation or a decrease of $12 \times 10^{-6}$ atm with $\mathrm{CaCO}_{3}$ compensation. Even with $\mathrm{CaCO}_{3}$ compensation, to explain the ocean wide ${ }^{13} \mathrm{C} /{ }^{12} \mathrm{C}$ change, the Holocene atmospheric $\mathrm{CO}_{2}$ content would have been ca $12 \times 10^{-6}$ atm lower than the glacial content. Some other change must have occurred that produced an $87 \times 10^{-6} \mathrm{~atm}$ glacial to Holocene increase in atmospheric $\mathrm{CO}_{2}$ content $\left(i e\right.$, the observed $75 \times 10^{-6}$ atm change increase plus the $12 \times 10^{-6}$ atm organic-reservoir-induced decrease).

\section{THE BIOLOGIC PUMP EFFECT}

The alternatives to Broecker's shelf hypothesis also involve changes in the operations of the "biologic pump," which transports carbon fixed by photosynthesis in surface waters to the interior of the ocean as organic 
debris. As this debris is ultimately oxydized returning its carbon to solution, at steady state the $\Sigma \mathrm{CO}_{2}$ content of surface waters is depleted and that of subsurface waters correspondingly enriched. A measure of the current effectiveness of this pump is given by model calculations for a steady state abiotic ocean. For such an ocean the $\mathrm{CO}_{2}$ pressure would be $450 \times 10^{-6}$ (as opposed to $275 \times 10^{-6}$ atm for the pre-anthropogenic value atmosphere). Thus, the biologic pumping action in today's ocean produces a $40 \%$ reduction in atmospheric $\mathrm{CO}_{2}$ content.

Working against the influence of settling organic tissue debris is the cycling of the $\mathrm{CaCO}_{3}$ hard parts of marine organisms. The formation of $\mathrm{CaCO}_{3}$ in surface waters (which would reduce alkalinity and increase $\mathrm{CO}_{2}$ pressure) and its dissolution in subsurface waters (which would increase alkalinity) partly compensates for the reduction in $\mathrm{CO}_{2}$ pressure caused by the cycle of organic matter. If for each mole of carbon that falls as organic debris, one mole of carbon were to fall as $\mathrm{CaCO}_{3}$, then the two processes would nearly cancel. However, in today's ocean the ratio of $\mathrm{CaCO}_{3}$ carbon to organic tissue carbon falling from the sea surface is considerably less than unity (it is ca 1 mole of $\mathrm{CaCO}_{3}$ carbon to 4 moles of organic tissue carbon). Thus, only partial compensation occurs.

There are two ways in which the biologic pumping action may have differed during glacial time. The strength of the pumping action via the organic cycle may have been stronger and the counter pumping action of the $\mathrm{CaCO}_{3}$ cycle may have been weaker.

Broecker's shelf hypothesis involves the removal at the onset of Holocene time of $\mathrm{NO}_{3}$ and $\mathrm{PO}_{4}$ from the ocean into shelf sediments. With less limiting nutrients present in the ocean, the effectiveness of the ocean's biologic pump is correspondingly reduced. Using our PANDORA model (see Appendix) in the absence of other effects, the $\mathrm{CO}_{2}$ content of the atmosphere is increased by $6.7 \%$ for each $10 \%$ that the ocean content of limiting nutrient content is reduced. To increase the $\mathrm{CO}_{2}$ content of the atmosphere from 200 to $275 \mathrm{ppm}$ would require a $50 \%$ decrease in $\mathrm{PO}_{4}$ (and in $\mathrm{NO}_{3}$ ) at the close of glacial time.

Alternatively, Broecker (1982b) suggested that the $\mathrm{CO}_{2}$ change could be induced by decreasing (from glacial to interglacial time) the ratios of carbon to nitrogen and carbon to phosphorus in the falling organic debris. Using our PANDORA model for each $10 \%$ the ratios are reduced, the atmospheric $\mathrm{CO}_{2}$ content rises by $6.7 \%$. For this mechanism to increase the $\mathrm{CO}_{2}$ content of the atmosphere from 200 to $275 \mathrm{ppm}$ would require a $50 \%$ decrease in $\mathrm{C} / \mathrm{P}$ and $\mathrm{C} / \mathrm{N}$ ratios in falling organic debris at the close of glacial time.

Three groups independently conceived another means of modifying the biologic pumping action (Sarmiento \& Toggweiler, 1984; Siegenthaler \& Wenk, 1984; Knox \& McElroy, 1984). They point out that the $\mathrm{CO}_{2}$ content of the atmosphere is sensitive to the limiting nutrient content of high latitude surface waters. Limiting nutrient contents in today's high latitude surface waters range from $40 \%$ to $80 \%$ of the mean ocean content. Thus, the biologic pump is not operating at full capacity in these regions as it is in warm surface ocean where the limiting nutrient concentrations are generally very low. Using our PANDORA model we find that for each $10 \%$ 
reduction in the limiting nutrient content of polar surface waters, the $\mathrm{CO}_{2}$ content of the atmosphere drops by ca $5 \%$. Thus, a $50 \%$ decrease in the nutrient content of polar surface waters would be required to give a $75 \times$ $10^{-6}$ atm $\mathrm{pCO}_{2}$ increase at the close of glacial time.

The shelf removal, residue composition, and polar nutrient scenarios all produce similar changes in the $\delta^{13} \mathrm{C}$ difference between warm Pacific surface and deep Pacific water per unit atmospheric $\mathrm{CO}_{2}$ pressure change (ie, ca $10 \mathrm{ppm} \mathrm{CO}_{2}$ partial pressure increase per $0.1 \% 0 \Delta \delta^{13} \mathrm{C}$ decrease). Taking advantage of this near uniformity in response, Shackleton et al (1983) used the temporal records for the planktonic species $N$ dutertrei and for the benthic species Uvigerina in a Pacific core to provide an estimate of the long-term record of the $\mathrm{CO}_{2}$ in the atmosphere. Their results nicely match the ice core $\mathrm{CO}_{2}$ record. This finding supports the idea that the $\mathrm{CO}_{2}$ change has its roots in ocean nutrient cycle changes. It does not, however, aid in distinguishing among the various possibilities.

It should be stressed that just as all three nutrient hypotheses call on roughly the same tie between the atmospheric $\mathrm{p}_{\mathrm{CO}_{2}}$ and $\Delta \delta^{13} \mathrm{C}$ change, they also call on roughly the same tie between the atmospheric $\mathrm{p}_{\mathrm{CO}_{2}}$ and deep ocean $\mathrm{O}_{2}$ concentration change. To explain the low $\mathrm{p}_{\mathrm{CO}_{2}}$ in the glacial atmosphere, they all demand a major reduction in deep sea $\mathrm{O}_{2}$ content during glacial time. As mentioned above, this has been problematic as there is no strong message from the organic carbon content of sediments that low bottom water $\mathrm{O}_{2}$ contents existed during glacial time. In reconsidering this situation, we conclude that while the evidence is convincing that the deep sea did not become anaerobic during glacial time, it is not inconsistent with a considerably lower deep water $\mathrm{O}_{2}$ content. For areas well away from the continents the rain rate of organic material to the sea floor is so low today that the sediments are nearly free of organic matter. It is entirely possible that this situation would prevail even if the $\mathrm{O}_{2}$ content of the bottom waters were quite a bit lower. If so, then open ocean sediments have nothing to tell us about bottom water $\mathrm{O}_{2}$. Closer to the continents where the rain rate of organic material is considerably higher, the content of organic compounds in the sediment is also higher. In several areas higher organic carbon content in these sediments are reported for glacial time. While these higher contents are usually interpreted as the result of higher rain rate of organic debris, they are equally well explained by lower bottom water $\mathrm{O}_{2}$ content. There is as yet no way to distinguish among these hypotheses; hence, we conclude that the continental margin sediment organic carbon content record is at least consistent with lower glacial bottom water $\mathrm{O}_{2}$ contents.

\section{DISTINGUISHING AMONG THE VARIOUS NUTRIENT HYPOTHESES}

The task is then to determine which of the nutrient hypotheses is correct. The three hypotheses make quite different predictions for the distribution of nutrient constituents within the sea between glacial and interglacial time. The shelf hypothesis calls upon a higher nutrient concentration everywhere in the sea during glacial time. The Redfield hypothesis requires no change at all. The polar nutrient hypothesis calls for a change for only high latitude surface waters. Boyle et al (1976), Bruland, Knauer and Mar- 
tin (1978) and Bruland (1980) show that cadmium and phosphate have identical distributions in today's ocean. Hester and Boyle (1982) show that the $\mathrm{Cd} / \mathrm{Ca}$ in benthic foraminifera shells is proportional to the $\mathrm{Cd} / \mathrm{Ca}$ ratio in seawater. As Ca is uniformly distributed through the sea and should not vary in concentration on a glacial to interglacial time scale, temporal changes in the $\mathrm{Cd} / \mathrm{Ca}$ of benthic forams should reflect changes in the $\mathrm{Cd}$ content of bottom water at the site where the core was taken. Recently Boyle (pers commun) showed that this method might be extended to certain species of planktonic foraminifera. If so, the potential exists to reconstruct the cadmium distribution throughout the glacial ocean.

If the $\mathrm{Cd} / \mathrm{P}$ ratio for the organic residues buried in sediments is similar to the seawater ratio, then the glacial to interglacial change in the mean ocean cadmium content also provides an estimate of the glacial to interglacial change in ocean $\mathrm{PO}_{4}$ content. Using this approach, Boyle has made a preliminary estimate that the $\mathrm{PO}_{4}$ content of the ocean was ca $20 \%$ higher during glacial time than it is now (Boyle, in press; Boyle \& Keigwin, 1985). While in the direction predicted by the shelf hypothesis, the corresponding atmospheric $\mathrm{CO}_{2}$ change is only $24 \times 10^{-6} \mathrm{~atm}$. This change is too small to be the primary cause of observed glacial to interglacial atmospheric $\mathrm{CO}_{2}$ change.

Another potential means for distinguishing among the nutrientbased hypotheses is to look for changes in the distribution of ${ }^{13} \mathrm{C} /{ }^{12} \mathrm{C}$ within the sea. Two processes leave their imprint on the ocean's ${ }^{13} \mathrm{C} /{ }^{12} \mathrm{C}$ distribution. First, organic material falling from the surface ocean is depleted in ${ }^{13} \mathrm{C}$ by ca $18 \% 0$ (relative to surface water $\Sigma \mathrm{CO}_{2}$ ). Thus, the cycle of organic matter gives the $\Sigma \mathrm{CO}_{2}$ in surface waters of the ocean a higher ${ }^{13} \mathrm{C} /{ }^{12} \mathrm{C}$ ratio than the $\mathrm{\Sigma CO}_{2}$ in deep waters. Second, temperature differences along the ocean surface lead to differences in the equilibrium isotope fractionation between atmospheric $\mathrm{CO}_{2}$ and surface ocean $\Sigma \mathrm{CO}_{2}$. The tendency is to give the $\Sigma \mathrm{CO}_{2}$ in cold surface water a higher ${ }^{13} \mathrm{C} /{ }^{12} \mathrm{C}$ ratio than that for the $\Sigma \mathrm{CO}_{2}$ in warm surface waters. Because in today's ocean the limiting nutrient content is higher in the cold surface waters than in the warm surface waters, the biologic tendency and temperature tendency for distributing ${ }^{13} \mathrm{C}$ are opposed (ie, the one tends to give cold surface waters a lower ${ }^{13} \mathrm{C} /{ }^{12} \mathrm{C}$ than warm surface waters, and the other one tends to give cold surface waters a higher ${ }^{13} \mathrm{C} /{ }^{12} \mathrm{C}$ than warm surface waters).

Mixing among the reservoirs tends to eliminate the ${ }^{13} \mathrm{C} /{ }^{12} \mathrm{C}$ differences within the sea. However, as the biologic processes are directly coupled to the mixing cycle while the exchange of $\mathrm{CO}_{2}$ between air and sea is not; mixing is more effective in smoothing differences created by surface ocean temperature gradients than those created by the photosynthesis-respiration cycle.

The ${ }^{13} \mathrm{C} /{ }^{12} \mathrm{C}$ ratio in any part of the sea could have changed from glacial to interglacial time for three quite different reasons.

1) As discussed above, the net removal from the atmosphere-ocean system of carbon as organic matter will change the ${ }^{13} \mathrm{C} /{ }^{12} \mathrm{C}$ ratio of bulk marine carbon. The living biosphere, soil carbon, and marine sediments are the major reservoirs of organic carbon likely to change on an interglacial to glacial time scale. 
2) Because the nutrient and ${ }^{13} \mathrm{C} /{ }^{12} \mathrm{C}$ ratio cycles in the sea have a nearly stoichiometric relationship, any change in the distribution of nutrients will lead to a corresponding change in the distribution of ${ }^{13} \mathrm{C} /{ }^{12} \mathrm{C}$ ratios.

3) The extent to which isotope equilibrium is established between waters of different temperature at the sea surface depends on the ratio of the air-sea $\mathrm{CO}_{2}$ exchange rate to the rates of mixing within the sea. The limiting distributions are shown in the appendix.

In addition to the complexities in the factors controlling the ${ }^{13} \mathrm{C} /{ }^{12} \mathrm{C}$ distribution in the sea, there are problems with the use of the ${ }^{13} \mathrm{C} /{ }^{12} \mathrm{C}$ ratios measured in foraminifera as proxies for sea water. Suspicions have arisen that one of the mainstay groups of benthonic foraminifera used in this work, Uvigerina peregrina is not a valid recorder of ${ }^{13} \mathrm{C} /{ }^{12} \mathrm{C}$ ratio. Zahn, Winn and Sarntheim (in press), make a very strong case that the ${ }^{13} \mathrm{C} /{ }^{12} \mathrm{C}$ ratio in the shells of these organisms is related to the amount of organic carbon in the sediment. This may well result from the fact that these organisms live within the sediment. McCorkle, Emerson and Quay (1985) show that the ${ }^{13} \mathrm{C} /{ }^{12} \mathrm{C}$ ratio in the sediment pore waters is influenced by the oxidation of organic matter. This finding throws the field into temporary disarray which makes difficult any synthesis of the ${ }^{13} \mathrm{C} /{ }^{12} \mathrm{C}$ distribution in the glacial ocean.

Putting aside these possible biases, the existing ${ }^{13} \mathrm{C}$ data suggests the following:

1) The ${ }^{13} \mathrm{C} /{ }^{12} \mathrm{C}$ ratio for average ocean water was lower by ca $0.5 \%$ during glacial time. However, as in some of the areas where the benthic records were obtained, the organic content of glacial sediment is higher than that of interglacial sediment. Part of this $0.5 \%$ change may be a porewater-induced bias rather than a whole ocean change.

2) The difference between the $\delta^{13} \mathrm{C}$ value for warm surface water and deep water appears to have been larger during glacial than interglacial time as predicted by the three nutrient models. However, the above-mentioned pore-water bias may account for part of this difference. Also, planktonic records are noisy and differ from place to place.

3) Planktonic forams from glacial sediments in the Antarctic have 0.5 to $1.0 \%$ lower ${ }^{13} \mathrm{C} /{ }^{12} \mathrm{C}$ ratios than their Holocene counterparts (Shackleton, pers commun; Mix \& Fairbanks, pers commun). As polar nutrient scenarios call for a change in the opposite sense, this result is potentially damning.

4) Measurements on $\mathrm{CO}_{2}$ from polar ice show a $1.0 \%$ lower glacial than Holocene $\delta^{13} \mathrm{C}$ value (Friedli et al, 1984). These authors do not take the result very seriously as the work was done on the Camp Century ice core which was stored for almost 20 years. Also, as no $\mathrm{N}_{2} \mathrm{O}$ correction was made, the apparent ${ }^{13} \mathrm{C} /{ }^{12} \mathrm{C}$ change could be due to a several times higher glacial $\mathrm{N}_{2} \mathrm{O}$ content. Most modelers hope that these results are influenced by storage or an $\mathrm{N}_{2} \mathrm{O}$ artifact for they are inconsistent with all explanations for atmospheric $\mathrm{pCO}_{2}$ change. Because of questions regarding the reliability of planktonic records in reconstructing the surface ocean $\delta^{13} \mathrm{C}$ history, it is essential that the glacial to interglacial $\delta^{13} \mathrm{C}$ change for $\mathrm{CO}_{2}$ from polar ice caps be precisely determined. 
The only means by which the $\mathrm{CaCO}_{3}$ cycle could lead the observed rapid atmospheric $\mathrm{CO}_{2}$ change is through its impact on the biologic pump. As discussed above, the $\mathrm{CaCO}_{3}$ cycle in today's ocean partly compensates for the reduction in $\mathrm{pCO}_{2}$ caused by the cycle of organic matter. To achieve a $\mathrm{pCO}_{2}$ reduction approaching $75 \times 10^{-6}$ atm in our PANDORA model $\mathrm{CaCO}_{3}$ production would have to be stopped entirely. As calcite accumulation rates for portions of the sea floor extending above the lysocline, where measured, are higher during glacial than Holocene time (see Broecker \& Peng, 1982 for summary), it is unlikely that the explanation for the glacial $\mathrm{pCO}_{2}$ reduction has to do with the $\mathrm{CaCO}_{3}$ cycle.

\section{BEYOND CARBON CYCLE: 1985}

The most likely causes for the glacial to Holocene increase in atmospheric $\mathrm{CO}_{2}$ content involve redistribution of carbon within the sea. Only in this way can the magnitude and rapidity of the $\mathrm{CO}_{2}$ changes be explained. To find out the cause of this redistribution we must learn far more than we do now about the operation of the ocean during glacial time. Today, roughly half of the new deep water forms in the northern Atlantic. The situation must have been quite different during glacial time. We know from the cadmium measurements of Boyle that the contrast between the limiting nutrient content of the waters of the deep Atlantic and the deep Pacific was smaller during glacial time than now. We also know from the CLIMAP results that the surface waters of the northern Atlantic $\left(>45^{\circ} \mathrm{N}\right)$ were 7 to $11^{\circ} \mathrm{C}$ colder during glacial time than today. There is also evidence for more extensive floating ice cover in both polar regions during glacial time. The reorganization of deep water circulation which brought the ocean from its glacial to its interglacial mode of operation in all likelihood also caused the increase in atmospheric $\mathrm{CO}_{2}$ content.

If we are to understand what happened we must greatly improve our knowledge of the patterns and rates of deep water ventilation during glacial time. To do this we must not only learn about changes in the distribution of cadmium and of ${ }^{13} \mathrm{C} /{ }^{12} \mathrm{C}$ between glacial and Holocene time, but also of the changes in the distribution of ${ }^{14} \mathrm{C} / \mathrm{C}$. Broecker et al (1984) and Andrée et al (1986) show, through measurements of ${ }^{14} \mathrm{C} /{ }^{12} \mathrm{C}$ ratios in planktonic and benthic foraminifera separated from successive horizons in deep sea cores, that it should be possible to obtain estimates of the ventilation rate of various deep-sea reservoirs during glacial time. Indeed, the first successful application of this new method is reported at this conference. Andrée et al (1986) suggest, from ${ }^{14} \mathrm{C} /{ }^{12} \mathrm{C}$ measurements on foraminifera from deep sea cores, that the ventilation rate of the deep Pacific Ocean was about the same during the early Holocene as today.

To illustrate the impacts of a change in mixing rate we compare the properties of our PANDORA model, run at its standard mixing rate, with the properties when all the mixing fluxes are reduced by a factor of two (Table 1). The air-sea $\mathrm{CO}_{2}$ exchange rate and the biologic residence times for the limiting nutrients are held constant. The surface to deep $\Delta^{14} \mathrm{C}$ differences double and the atmospheric $\Delta^{14} \mathrm{C}$ rises by $83 \% 0$. The $\mathrm{PO}_{4}$ content 
TABLE 1

Comparison between the properties of the standard PANDORA model (lower number in each box) and the PANDORA model run with all the water mixing rates cut to one half (upper number in each box).

\begin{tabular}{|c|c|c|c|c|c|c|c|c|}
\hline $\begin{array}{c}\text { Reservoir } \\
\text { no. }\end{array}$ & $\begin{array}{c}\text { Reservoir } \\
\text { name }\end{array}$ & $\begin{array}{c}\mathrm{PO}_{4} \\
\mu \mathrm{m} / \mathrm{kg}\end{array}$ & $\begin{array}{l}\mathrm{AOU}^{*} \\
\mu \mathrm{m} / \mathrm{kg}\end{array}$ & $\begin{array}{l}\mathrm{H}_{4} \mathrm{SiO}_{4} \\
\mu \mathrm{m} / \mathrm{kg}\end{array}$ & $\begin{array}{c}\mathrm{CO}_{3}^{-} \\
\mu \mathrm{m} / \mathrm{kg}\end{array}$ & $\begin{array}{l}\mathrm{pCO}_{2} \\
\mu \mathrm{atm}\end{array}$ & $\begin{array}{c}\delta^{13} \mathrm{C} \\
\% 0\end{array}$ & $\begin{array}{c}\Delta^{14} \mathrm{C} \\
\% 0\end{array}$ \\
\hline & Atmosphere & & & & & & & 83 \\
\hline & & & & & & 282 & -6.6 & 0 \\
\hline \multirow{2}{*}{2} & Atlantic & 0.01 & 0 & 0 & 229 & 248 & 2.3 & 55 \\
\hline & surface & 0.03 & -1 & 0 & 213 & 280 & 2.5 & -30 \\
\hline \multirow{2}{*}{9} & INDOPAC & 0.01 & 0 & 0 & 236 & 246 & 2.2 & 37 \\
\hline & $\begin{array}{l}\text { warm } \\
\text { surface }\end{array}$ & 0.03 & -1 & 0 & 223 & 279 & 2.3 & -46 \\
\hline \multirow{2}{*}{1} & No. Atlantic & 0.69 & 3 & 21 & 143 & 234 & 2.1 & -33 \\
\hline & surface & 0.96 & 6 & 19 & 130 & 268 & 2.0 & -78 \\
\hline \multirow{2}{*}{6} & Antarctic & 1.50 & 1 & 60 & 130 & 252 & 3.0 & -65 \\
\hline & $\begin{array}{l}\text { coid } \\
\text { surface }\end{array}$ & 1.68 & 2 & 73 & 119 & 289 & 2.5 & -110 \\
\hline \multirow{2}{*}{11} & No. Pacific & 1.37 & 1 & 46 & 151 & 268 & 2.6 & -155 \\
\hline & $\begin{array}{l}\text { cold } \\
\text { surface }\end{array}$ & 1.66 & 2 & 72 & 136 & 320 & 2.1 & -160 \\
\hline \multirow{2}{*}{4} & Atlantic & 1.20 & 80 & 55 & 118 & 316 & 1.6 & -139 \\
\hline & $\begin{array}{l}\text { deep } \\
\text { water }\end{array}$ & 1.39 & 72 & 47 & 113 & 338 & 1.5 & -129 \\
\hline \multirow{2}{*}{7} & Antarctic & 2.16 & 207 & 112 & 79 & 538 & 1.2 & -171 \\
\hline & $\begin{array}{l}\text { deep } \\
\text { water }\end{array}$ & 2.04 & 148 & 105 & 87 & 477 & 1.2 & -156 \\
\hline \multirow{2}{*}{10} & INDOPAC & 2.79 & 335 & 142 & 53 & 917 & 0.6 & -217 \\
\hline & $\begin{array}{l}\text { deep } \\
\text { water }\end{array}$ & 2.51 & 244 & 146 & 66 & 705 & 0.7 & -184 \\
\hline
\end{tabular}

*Atmosphere equilibrium $\mathrm{O}_{2}$ content minus in situ oxygen content (ie, Apparent Oxygen Utilization).

of the cold surface water reservoirs drops as does the $\mathrm{CO}_{2}$ content of the atmosphere and the oxygen content of the deep sea. The ${ }^{13} \mathrm{C} /{ }^{12} \mathrm{C}$ ratio for the cold surface ocean reservoirs rises. However, the surface to deep $\delta^{13} \mathrm{C}$ difference for the combined Indian and Pacific Oceans remains unchanged.

The task of understanding all the interactions in the model that combine to set today's limiting nutrient, dissolved oxygen, $\mathrm{CO}_{2}$ partial pressure, $\mathrm{CO}_{3}^{-}$ion content, ${ }^{13} \mathrm{C} /{ }^{12} \mathrm{C}$ and ${ }^{14} \mathrm{C} /{ }^{12} \mathrm{C}$ distributions in the ocean atmosphere system is a complex one. We give one more example from PANDORA. A run was made in which the $\mathrm{CO}_{2}$ exchange rate for the Antarctic surface reservoir is reduced by a factor of three. All other parameters are kept the same as in the standard case. This change simulates the impact of a much larger mean ice cover in the Antarctic during glacial time. Table 2 
TABLE 2

Comparison between the properties of the standard PANDORA model (lower number in each box) and the PANDORA model with $\mathrm{CO}_{2}$ exchange for the surface Antarctic (reservoir 6) reduced by a factor of three (upper number in each box).

\begin{tabular}{|c|c|c|c|c|c|c|c|c|}
\hline $\begin{array}{l}\text { Reservoir } \\
\text { no. }\end{array}$ & $\begin{array}{l}\text { Reservoir } \\
\text { name }\end{array}$ & $\begin{array}{c}\mathrm{PO}_{4} \\
\mu \mathrm{m} / \mathrm{kg}\end{array}$ & $\begin{array}{c}\mathrm{AOU} \\
\mu \mathrm{m} / \mathrm{kg}\end{array}$ & $\begin{array}{l}\mathrm{H}_{4} \mathrm{SiO}_{4} \\
\mu \mathrm{m} / \mathrm{kg}\end{array}$ & $\begin{array}{c}\mathrm{CO}_{3}^{-} \\
\mu \mathrm{m} / \mathrm{kg}\end{array}$ & $\begin{array}{l}\mathrm{pCO}_{2} \\
\mu \mathrm{atm}\end{array}$ & $\begin{array}{c}\delta^{13} \mathrm{C} \\
\% 0\end{array}$ & $\begin{array}{c}\Delta^{14} \mathrm{C} \\
\% 0\end{array}$ \\
\hline & Atmosphere & & & & & 280 & -6.3 & 18 \\
\hline & & & & & & 282 & -6.6 & 0 \\
\hline \multirow{2}{*}{2} & Atlantic & 0.03 & -1 & 0 & 213 & 279 & 2.7 & -18 \\
\hline & surface & 0.03 & -1 & 0 & 213 & 280 & 2.5 & -30 \\
\hline \multirow[t]{2}{*}{9} & INDOPAC & 0.03 & -1 & 0 & 224 & 277 & 2.5 & -33 \\
\hline & surface & 0.03 & -1 & 0 & 223 & 279 & 2.3 & -46 \\
\hline \multirow[t]{2}{*}{1} & $\begin{array}{l}\text { No. Atlantic } \\
\text { cold }\end{array}$ & 0.96 & 6 & 19 & 131 & 267 & 2.1 & -70 \\
\hline & surface & 0.96 & 6 & 19 & 130 & 268 & 2.0 & -78 \\
\hline \multirow[t]{2}{*}{6} & $\begin{array}{l}\text { Antarctic } \\
\text { cold }\end{array}$ & 1.68 & 4 & 73 & 116 & 298 & 2.0 & -142 \\
\hline & surface & 1.68 & 2 & 73 & 119 & 289 & 2.5 & -110 \\
\hline \multirow{2}{*}{11} & No. Pacific & 1.64 & 2 & 72 & 136 & 319 & 2.1 & -161 \\
\hline & surface & 1.66 & 2 & 72 & 136 & 320 & 2.1 & -160 \\
\hline \multirow{2}{*}{4} & $\begin{array}{l}\text { Atlantic } \\
\text { deep }\end{array}$ & 1.39 & 73 & 47 & 113 & 337 & 1.7 & -125 \\
\hline & water & 1.39 & 72 & 47 & 113 & 338 & 1.5 & -129 \\
\hline \multirow{2}{*}{7} & Antarctic & 2.04 & 149 & 105 & 87 & 481 & 1.1 & -164 \\
\hline & water & 2.04 & 148 & 105 & 87 & 477 & 1.2 & -156 \\
\hline \multirow{2}{*}{10} & $\begin{array}{l}\text { INDOPAC } \\
\text { deep }\end{array}$ & 2.51 & 245 & 146 & 66 & 709 & 0.6 & -188 \\
\hline & wate & 2.51 & 244 & 146 & 66 & 705 & 0.7 & -184 \\
\hline
\end{tabular}

shows this change has an impact on the ${ }^{13} \mathrm{C} /{ }^{12} \mathrm{C}$ and ${ }^{14} \mathrm{C} /{ }^{12} \mathrm{C}$ distribution in the ocean and none on the $\mathrm{CO}_{2}$ or $\mathrm{O}_{2}$ distribution (nor, of course, on the limiting nutrient distribution). In this way, a $0.5 \% 0$ decrease in the $\delta^{13} \mathrm{C}$ value for the surface of the Antarctic can be made without greatly influencing any other aspect of the property distributions. We should hasten to add, however, that an increase in ice cover large enough to reduce the gas exchange rate by a factor of three would surely alter the biologic residence time of the limiting nutrients. If so, far more extensive changes in the models' property distributions would occur.

\section{CONCLUSIONS}

The last word has yet to be said about the significance of the glacial to interglacial $\mathrm{CO}_{2}$ changes observed for air extracted from ice cores. Several questions regarding key existing measurements must be answered. 
1) Are the sharp changes in $\mathrm{CO}_{2}$ content found for the brief warm events in the Greenland ice cores real or are they artifacts?

2) Do benthic and planktonic forams reliably record the glacial to interglacial ${ }^{13} \mathrm{C} /{ }^{12} \mathrm{C}$ ratio in deep and surface waters?

3) What is the ${ }^{13} \mathrm{C} /{ }^{12} \mathrm{C}$ change for the atmosphere between glacial and interglacial time as recorded in polar ice?

Also, several new techniques have to be further exploited.

1) The use of the cadmium content of foraminifera shells to yield estimates of the change in the distribution (and amount) of nutrients in the ocean during glacial time.

2) The use of benthic-planktonic ${ }^{14} \mathrm{C}$ age differences to yield estimates of the pattern and rate of deep ocean ventilation during glacial time.

3) A quantitative means of estimating the oxygen content of deep sea water must be found.

Once these observations are firmly in hand we will be better able to distinguish among the various hypotheses. This will require the development of more realistic models of the ocean's operation.

\section{ACKNOWLEDGMENTS}

The authors are particularly grateful to Steve Emerson for extensive discussions about the factors controlling the organic content of sediments and to Ed Boyle for keeping us up-to-date on his cadmium work. We also thank Hans Oeschger for allowing us to mention some of his group's unpublished ice core data. The work by Broecker was performed for Carbon Dioxide Research Division, Office of Energy Research, under Subcontract No. 19X-22237C, with Lamont-Doherty Geological Observatory of Columbia University with Martin Marietta Energy System, Inc, under Contract No. DE-AC05-840R21400 with the US Department of Energy. The research by Peng at Oak Ridge National Laboratory was supported jointly by the National Science Foundation's Ecosystem Studies Program under Interagency Agreement BSR-8417923 and the Carbon Dioxide Research Division, Office of Energy Research, US Department of Energy, under Contract DE-AC05-840R21400 with Martin Marietta Energy Systems, Inc, Environmental Sciences Division Publication No. 2738. Lamont-Doherty Geological Observatory Contribution No. 3993.

\section{APPENDIX}

\section{THE PANDORA MODEL}

In order to evaluate the impacts on the $\mathrm{CO}_{2}$ content of the atmosphere of possible differences between the operation of the glacial and the interglacial ocean-atmosphere system we have developed an 1 l-box global ocean model which operates something like the real system. Sarmiento and Toggweiler (1984), Siegenthaler and Wenk (1984), and Knox and McElroy (1984) show that it is necessary to separate the limiting nutrient-free mid- and low-latitude surface waters from the nutrient-rich high-latitude surface waters. We have gone a step further and separated the Atlantic from the Pacific-Indian Ocean.

Figure 1 shows the basic structure of our model, PANDORA. The individual reservoirs in this model are identified and the fraction of the ocean volume constituted by each reservoir is given. Also shown are the fractions of the ocean surface area attributed to each of the boxes with an atmospheric interface.

Figure 2 shows the flow pattern adopted for the model. We have minimized the exchange of water across box boundaries. Only for the boundaries of the deep Antarctic reservoir do two-way fluxes exist. The magnitudes of the fluxes were chosen to yield the observed 


\section{PANDORA}

THE SOMETHING LIKE THE REAL OCEAN GEOCHEMICAL MODEL

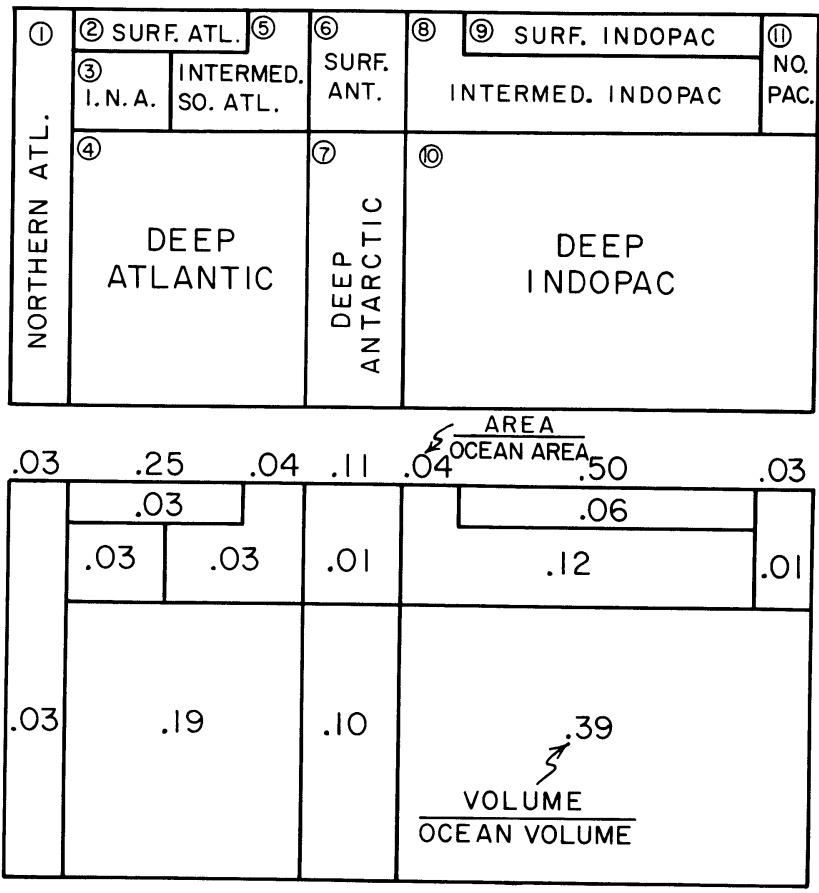

Fig 1. Basic structure of the PANDORA model ocean. The upper panel gives the names and numbers of the 11 reservoirs which make up the model ocean. The lower panel shows the fractions of the ocean's volume constituted by each reservoir and the fractions of the ocean's surface area occupied by those boxes having interfaces with the atmosphere. ${ }^{14} \mathrm{C}$ distribution in the ocean. The corresponding water residence times are also shown in Fig-
ure 2 .

The biologic redistribution of the limiting nutrients, $\mathrm{NO}_{3}$ and $\mathrm{PO}_{4}$, is controlled by the rules given in Figure 3. For each box that reaches the sea surface a nutrient residence time is assigned. These times refer to the removal of the limiting nutrients from the box to an underlying box as falling organic debris (nutrient recycling within a given box is not included). The fate of the organic debris falling from a given surface box is indicated by the designated percentages. Recycling is assumed to be complete. The values of the biologic residence times and of the destruction percentages are chosen to reproduce the observed $\mathrm{PO}_{4}$ (and $\mathrm{NO}_{3}$ ) distributions. The fluxes of organic carbon generated by the combination of the water-flow pattern and the rules governing the biologic redistribution of the limiting nutrient is also shown in Figure 3.

The silica cycle is handled in the same manner as the limiting nutrient cycle. However, a different set of biologic residence times and destruction percentages is needed to reproduce the observed silica distribution (Fig 4). Also shown (Fig 4) are the opal fluxes obtained when the water fluxes and biologic rules are applied to silica.

The cycle of $\mathrm{CaCO}_{3}$ is handled in a somewhat different manner. Instead of assigning biologic residence times to $\mathrm{Ca}$ in surface water, we tie the production of $\mathrm{CaCO}_{3}$ directly to the production of organic debris. In the warm surface reservoirs $(2$ and 9$)$ and in the intermediate reservoirs ( 5 and 8 ) we allow 1 mole of $\mathrm{CaCO}_{3}$ to fall for each 5 moles of organic residues which fall. In the cold reservoirs ( 6 and 11) we allow 2 moles of $\mathrm{CaCO}_{3}$ to fall from the reservoir for each 5 moles of organic residue. We redissolve a far greater percentage of the $\mathrm{CaCO}_{3}$ in the deep reservoirs than in the intermediate reservoirs. See Figure 5 for these rules and the 

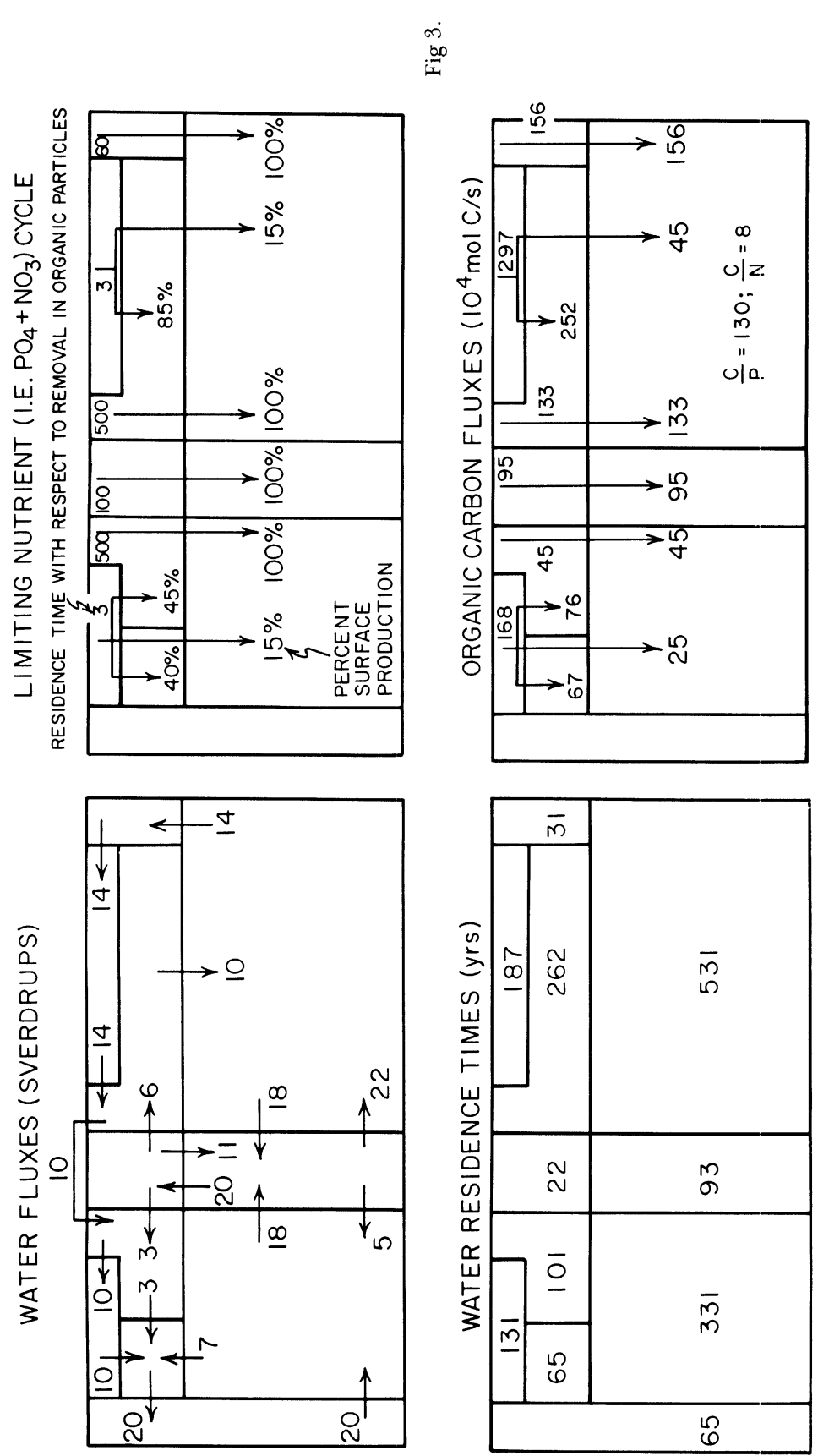

$\tilde{3})$ $\times 00^{\infty}$ oz:

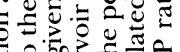

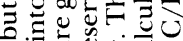

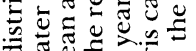
U. 3 更。 00

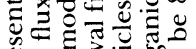

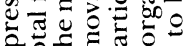

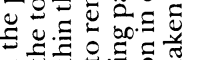
入े 3

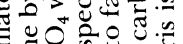

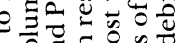

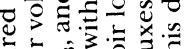

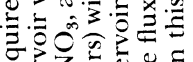

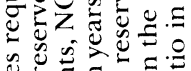

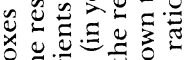

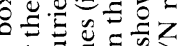

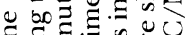

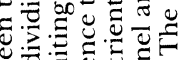

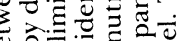

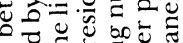

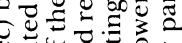
苋要 $\Xi \frac{\pi}{3}=\frac{2}{3}$ :U⿺辶寸

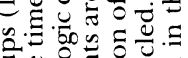
른.

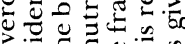
की

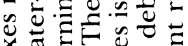
$30-$. . 政

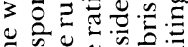

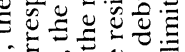
过㦴.

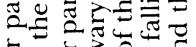

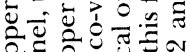
马ำ

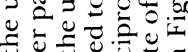

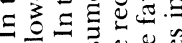

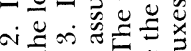

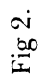
$30=000$

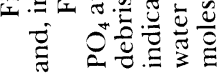




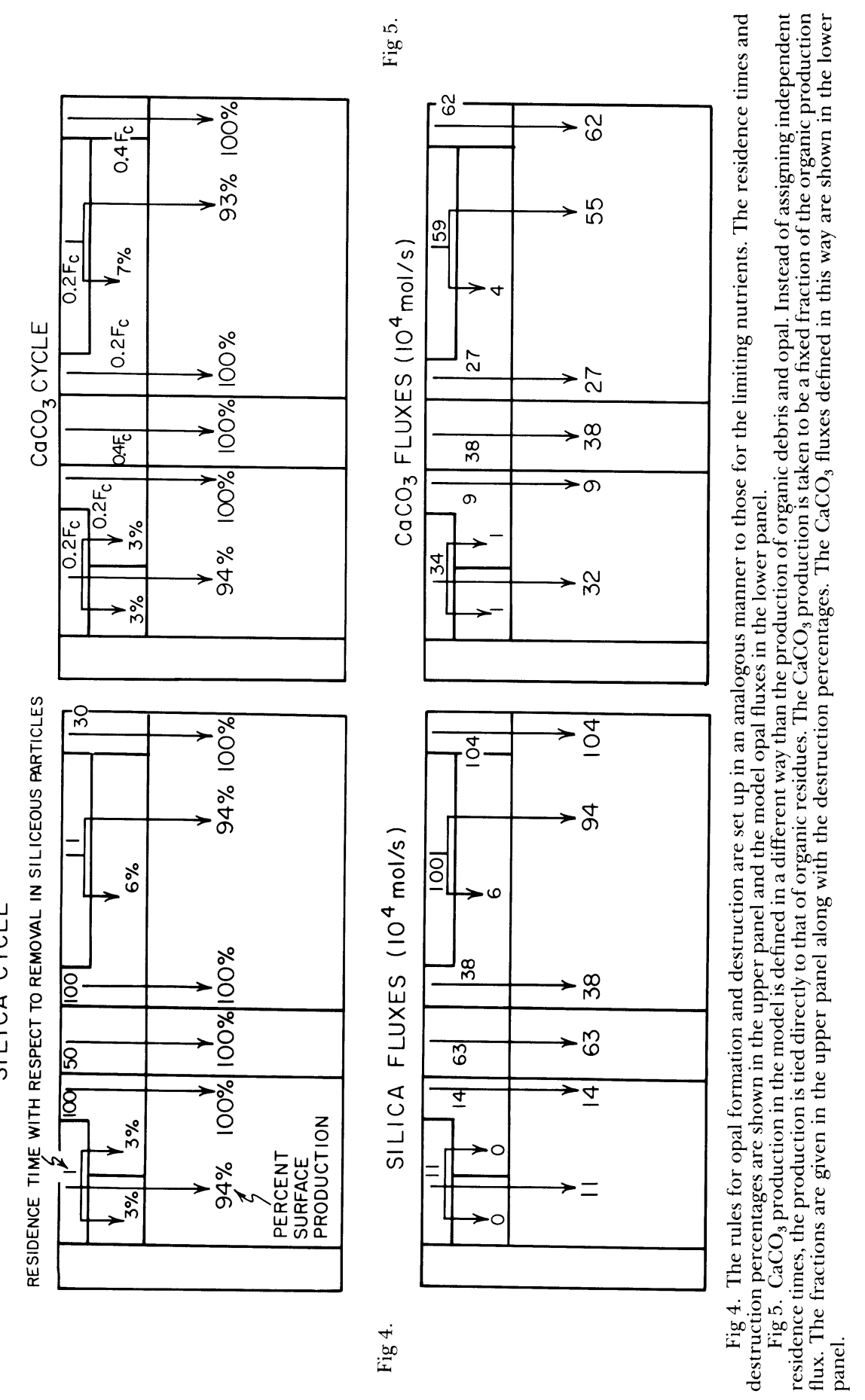




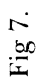
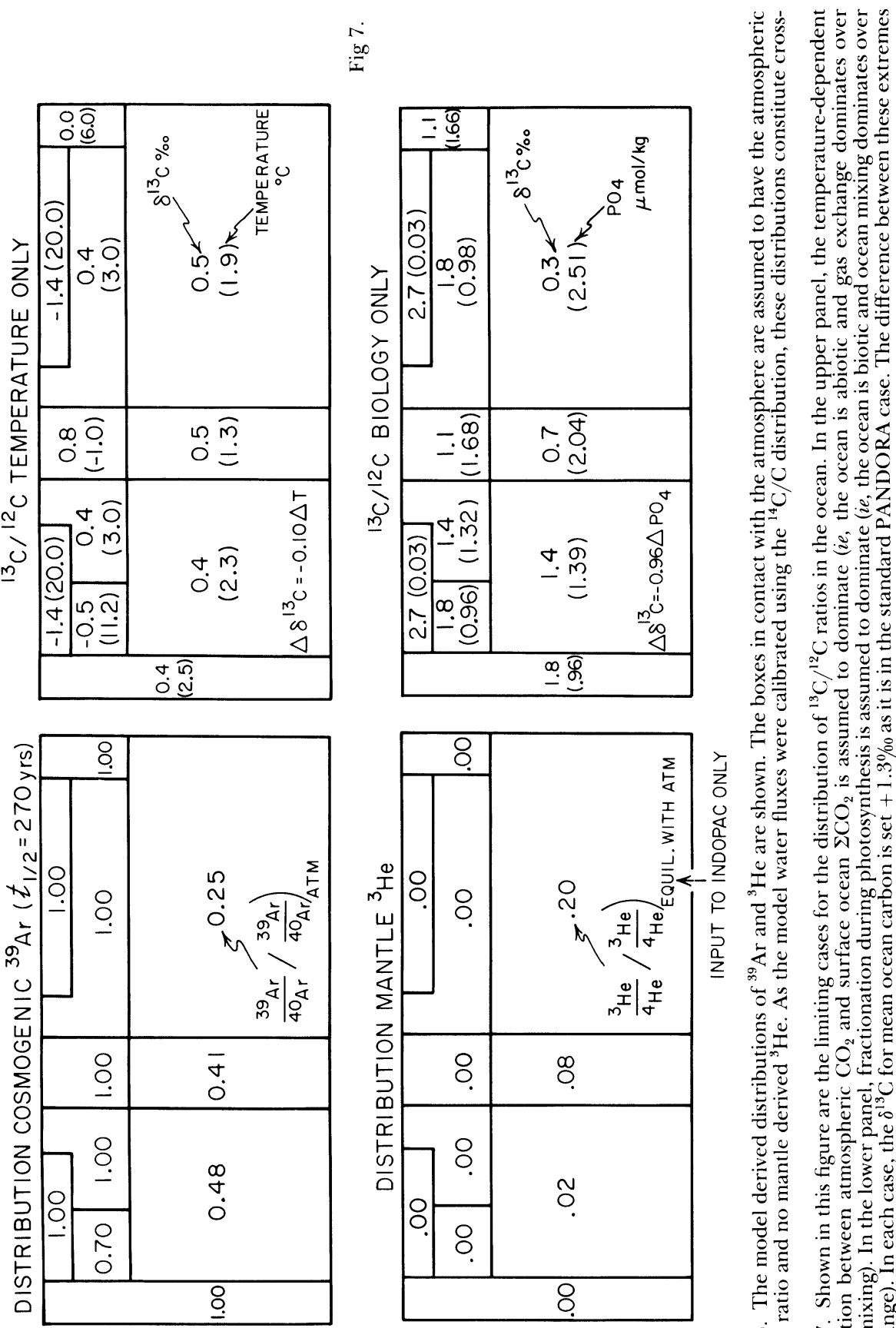

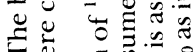

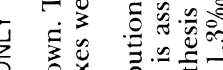

की $\mathrm{E}^{2} \mathrm{O}^{+}$

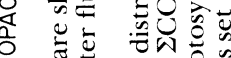

记苋

象

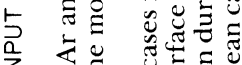

कo

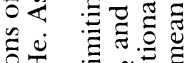

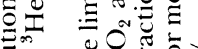

.

$\underset{10}{60}$

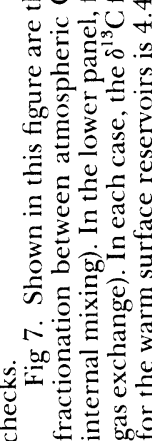


resulting $\mathrm{CaCO}_{3}$ fluxes. The rules are designed to reproduce the observed salinity normalized calcium distribution in the sea (as determined from the nitrate-corrected and salinity-normalized alkalinity distribution).

The only pertinent tracer properties of the ocean not utilized in calibrating the model are ${ }^{3} \mathrm{He},{ }^{39} \mathrm{Ar}$ and ${ }^{13} \mathrm{C} /{ }^{12} \mathrm{C}$. The predicted distributions of excess planetary ${ }^{3} \mathrm{He}$ (derived from mantle outgassing) and of cosmic-ray-produced ${ }^{39} \mathrm{Ar}$ are shown in Figure 6. For these calculations excess ${ }^{3} \mathrm{He}$ was added only to the deep Indopac reservoir (ie, not to the deep Antarctic and deep Atlantic reservoirs). In the case of ${ }^{39} \mathrm{Ar}$, the ratio to ${ }^{40} \mathrm{Ar}$ is maintained equal to that for the atmosphere in all the boxes with surface outcrops. For both isotopes the model distributions are consistent with what we know of the actual distributions.

The ${ }^{13} \mathrm{C} /{ }^{12} \mathrm{C}$ distribution in the ocean is of particular interest because of the conflicting influences of temperature and biology. If no biologic cycling or organic carbon occurred within the sea and if the equilibration between atmospheric $\mathrm{CO}_{2}$ and surface ocean $\Sigma \mathrm{CO}_{2}$ greatly outpaced mixing within the sea, then the cold surface waters of the ocean would have higher ${ }^{13} \mathrm{C} /{ }^{12} \mathrm{C}$ ratios than the warm waters (see upper panel, Fig 7). By contrast, if the rate of equilibration atmospheric $\mathrm{CO}_{2}$ and ocean carbon greatly outpaced mixing in this abiotic ocean the ${ }^{13} \mathrm{C} /{ }^{12} \mathrm{C}$ ratio would be the same in all the reservoirs. Biologic cycling of organic matter tends to give the cold waters (nutrient rich) lower ${ }^{13} \mathrm{C} /{ }^{12} \mathrm{C}$ ratios than the warm waters (nutrient poor). Thus, in the extreme where equilibration between the atmosphere's $\mathrm{CO}_{2}$ and the surface ocean's $\Sigma \mathrm{CO}_{2}$ is outpaced by mixing, the cold surface waters in the ocean would have lower ${ }^{13} \mathrm{C} /{ }^{12} \mathrm{C}$ ratios than the warm surface waters (see lower panel, Fig 7 ). The situation lies between these two extremes in the real ocean. The ratio of atmosphere-sea gas exchange rate to ocean mixing rate is such that the ${ }^{13} \mathrm{C} /{ }^{12} \mathrm{C}$ distribution in surface waters is influenced both by the temperature fractionation effect and the biologic fractionation effect.

\section{REFERENCES}

Andrée, M, Beer, J, Oeschger, H, Broecker, W, Mix, A, Ragano, N, O'Hara, P, Bonani, G, Hofmann, H J, Morenzoni, E, Nessi, M, Suter, M and Wölfli, W, 1984. ${ }^{14} \mathrm{C}$ Measurements on foraminifera of Deep Sea Core V28-238 and their preliminary interpretation: Nuclear Instruments \& Methods, v B5, p 340-345.

Andrée, M, Mix, A, Broecker, W, Beavan, N, Hofmann, H, Morenzoni, E, Nessi, M, Bonani, G, Suter, M and Wölfli, W, 1986, Accelerator radiocarbon dates on foraminifera from deep sea sediments, in Stuiver, M and Kra, R S, eds, Internatl ${ }^{14} \mathrm{C}$ conf, 12 th, Proc: Radiocarbon, this issue.

Barnola, J M, Raynaud, D, Neftel, D and Oeschger, H, 1983, Comparison of $\mathrm{CO}_{2}$ measurements by two laboratories on air bubbles in polar ice: Nature, $v$ 303, p 410-412.

Beer, J, Oeschger, H, Andrée, M, Bonani, G, Suter, M, Wölfli, W and Langway, CC, 1984, Temporal variations in the ${ }^{10} \mathrm{Be}$ concentration levels found in the Dye 3 ice core, Greenland: Annals Glaciol, v 5, p 6-17.

Berner, W, Oeschger $\mathrm{H}$ and Stauffer, B, 1980, Information on the $\mathrm{CO}_{2}$ cycle from ice core studies, in Stuiver, $\mathrm{M}$ and Kra, R S, eds, Internatl ${ }^{14} \mathrm{C}$ conf, 10th, Proc: Radiocarbon, v 22 ,
no. 2, p 227-235.

Berner, W, Stauffer, B and Oeschger, H, 1979, Past atmospheric composition and climate gas parameters measured on ice cores: Nature, v 275, p 53-55.

Boyle, E A, 1986, Paired cadmium and carbon isotope data in benthic foraminiferas: implications for changes in oceanic phosphorus, oceanic circulation and atmospheric carbon dioxide: Geochim et Cosmochim Acta, in press.

Boyle, E A and Keigwin, L D, 1985, Comparison of Atlantic and Pacific paleochemical records for the last 250,000 years: changes in deep ocean circulation and chemical inventories: Earth Planetary Sci Letters, v 76, p 135-150.

Boyle, E A, Schlater, F and Edmond, J M, 1976, On the marine geochemistry of cadmium: Nature, v 263, p 42-44.

Broecker, W S, 1971, A kinetic model for the chemical composition of sea water: Quaternary Research,v 1, p 188-207.

1981, Glacial to interglacial changes in ocean and atmosphere chemistry, in Berger, A, ed, Climatic variations and variability: Facts and theories: Boston, D Reidel Pub Co, p 109-120. 11, p 151-197. Glacial to interglacial changes in ocean chemistry: Progress in Oceanog, v p $1689-1705$.

- in press, Oxygen isotope constraints on surface ocean temperatures during glacial times: Quaternary Research.

Broecker, W S, Mix, A, Andrée, M and Oeschger, H, 1984, Radiocarbon measurements on coexisting benthic and planktic foraminifera shells: potential for reconstructing ocean 
ventilation times over the past 20,000 years: Nuclear Instruments \& Methods, v B5, p 331 .

Broecker, W S and Peng, T -H, 1982, Tracers in the sea: Palisades, New York, Eldigio Press, $690 \mathrm{p}$.

Broecker, W S, Takahashi, T and Takahashi, T, 1985, Sources and flow patterns of deep ocean waters as deduced from potential temperature, salinity and initial phosphate concentration: Jour Geophys Research, v 90, p 6925-6939.

Bruland, K W, 1980, Oceanographic distributions of $\mathrm{Cd}, \mathrm{Zn}, \mathrm{Ni}$ and $\mathrm{Cu}$ in the North Pacific: Earth Planetary Sci Letters, v 47, p 177-198.

Bruland, K W, Knauer, G A and Martin, J H, 1978, Cadmium in the northwest Pacific waters: Limnol \& Oceanog, v 23, p 618-625.

Dahl-Jensen, D, 1985, Determination of the flow properties at Dye 3, south Greenland, by bore-hole-tilting measurements and perturbation modelling: Jour Glaciol, v 31, p 9398.

Dansgaard, W, 1985, Greenland ice core studies: Paleog, Paleoclimatol, Paleobot, v 50, p $185-187$.

Dansgaard, W, Clausen, H B, Gundestrup, N, Hammer, C U, Johnsen, S J, Kristinsdottir, P M and Reeh, N 1982, A new Greenland deep ice core: Science, v 218 p 1273-1277.

Dansgaard, W, Johnsen, S J, Clausen, H B, Dahl-Jensen, D, Gundestrup, N and Hammer, C U, 1984, North Atlantic climatic oscillations revealed by deep Greenland ice cores, in Hansen, J E, and Takahashi, T, eds, Climate procésses and climate sensitivity: Geophys Mono 29, p 288-298.

Delmas, R J, Ascencio, J - M and Legrand, M, 1980, Polar ice evidence that atmospheric $\mathrm{CO}_{2}$ 29,000 yr BP was $50 \%$ of the present: Nature, v 284, p 155-157.

Friedli, $\mathrm{H}$, Moor, E, Oeschger, $\mathrm{H}$, Siegenthaler, $\mathrm{U}$ and Stauffer, $\mathrm{B}, 1984,{ }^{18} \mathrm{C} /{ }^{12} \mathrm{C}$ ratios in $\mathrm{CO}_{2}$ extracted from Antarctic ice: Geophys Research Letters, v 11, p 1145-1148.

Gundnerstrup, N S and Hansen, B L, 1984, Bore-hole survey at Dye 3 south Greenland: Jour Glaciol, v 30, p 282-288.

Hester, K and Boyle, E, 1982, Water chemistry control of the Cd content of benthic foraminifera: Nature, v 298, p 260-261.

Knox, $\mathrm{F}$ and McElroy, $\mathrm{M}, 1984$, Changes in atmospheric $\mathrm{CO}_{2}$ : influence of marine biota at high latitudes: Jour Geophys Research, v 89, p 4629-4637.

McCorkle, D, Emerson, S R and Quay, P D, 1985, Stable carbon isotopes in marine porewaters: Earth Planetary Sci Letters, v 74, p 13-26.

Neftel, A, Oeschger, H, Schwander, J, Stauffer, B and Zumbrunn, R, 1982, Ice core sample measurements give atmospheric $\mathrm{CO}_{2}$ content during the past 40,000 years: Nature, $v$ 295 , p 220-223.

Sarmiento, J L and Toggweiler, R, 1984, A new model for the role of the oceans in determining atmospheric $\mathrm{pCO}_{2}$. Nature, v 308, p 621-624

Schwander, J and Stauffer, B, 1984, Age difference between polar ice and the air trapped in its bubbles: Nature, v 311, p 45-47.

Shackelton, N J, 1977, Tropical rainforest history and the equatorial Pacific carbonate dissolution cycles, in Anderson, N R and Malahoff, A, eds, The fate of fossil fuel $\mathrm{CO}_{2}$ in the oceans: New York, Plenum Press, p 401-428.

Shackleton, N J, Hall, M A, Line, J and Shuxi, C, 1983, Carbon isotope data in core V19-30 confirm reduced carbon dioxide concentration in the ice age atmosphere: Nature, $v 306$, p 319-322.

Siegenthaler, $\mathrm{U}$ and Wenk, T, 1984, Rapid atmospheric $\mathrm{CO}_{2}$ variations and ocean circulation: Nature, v 308, p 624-626.

Stauffer, B, Hofer, H, Oeschger, H, Schwander, J and Siegenthaler, U, 1984, Atmospheric CO concentrations during the last glaciation: Annals Glaciol, v $5, \mathrm{p} 160-164$

Stauffer, B, Neftel, A, Oeschger, $\mathrm{H}$ and Schwander, J, 1985, $\mathrm{CO}_{2}$ concentration in air extracted from Greenland ice samples: AGU Geophys Mono ser, v 23, p 85-89.

Sundquist, E T and Broecker, W S, eds, 1985 , The carbon cycle and atmospheric $\mathrm{CO}_{2}$ : Natural variations archaean to present: Geophys Monog, v 32.

Takahashi, T, Broecker, W S and Langer, S, 1985, Redfield ratio based on chemical data from isopycnal surfaces: Jour Geophys Research, v 90, p 6907-6924.

Zahn, R, Winn, $\mathrm{K}$ and Sarntheim, M, in press, Benthic foraminiferal ${ }^{3} \mathrm{C}$ and microhabitats, evidence from the Uvigerina perigrina group and Cibicidoides wuellerstorfi: Paleooceanog. 